\title{
The Application of European Constitutional Values in EU Member States
}

\author{
The Case of the Fundamental Law of Hungary
}

Gábor Halmai

Abstract

This article deals with the backsliding of liberal democracy in Hungary, after 2010, and also with the ways in which the European Union (EU) has coped with the deviations from the shared values of rule of law and democracy in one of its Member States. The article argues that during the fight over the compliance with the core values of the EU pronounced in Article 2 TEU with the Hungarian government, the EU institutions so far have proven incapable of enforcing compliance, which has considerably undermined not only the legitimacy of the Commission but also that of the entire rule-of-law oversight.

Keywords: Article 2 and 7 TEU, democratic backsliding, Hungary, infringement procedure, rule-of-law mechanism.

\section{A Introduction}

This article deals with recent deviations from the shared values of rule of law and democracy - the 'basic structure' of Europe - in Hungary. The starting point of the deviation is Article 2 of the Treaty of the European Union (TEU), which demands "respect for human dignity, freedom, democracy, equality, rule of law and [...] human rights including the rights of minorities". The principles of Article 2 TEU are elaborated for candidate countries of the EU in the Copenhagen criteria, laid down in the decision by the European Council of 21 and 22 June 1993, to provide the prospect of accession for transitioning countries that still had to overcome authoritarian traditions. The TEU sets out the conditions, in Article 49, and principles, in Article 6(1), to which any country wishing to become an EU member must conform. Regarding constitutional democracy, the political criteria are decisive: stability of institutions guaranteeing democracy, rule of law, protection of human rights, and respect for, and protection of, minorities. This was the main instrument governing the greatest enlargement in EU history: starting in

* Professor and Chair of Comparative Constitutional Law, European University Institute, Department of Law, Florence. This volume (The EU Bill of Rights' Diagonal Application to Member States. Ed. Csongor István Nagy) was published as part of the research project of the HAS-Szeged Federal Markets 'Momentum' Research Group. 
2004 with ten new Member States, mostly former socialist countries, followed by the accession of Romania and Bulgaria in 2007 and concluded by the admission of Croatia in 2013. ${ }^{1}$ As Dimitry Kochenov argues, the assessment of democracy and the rule-of-law criteria during this enlargement was not really full, consistent and impartial, and the threshold to meet the criteria was very low. As a result, the Commission failed to establish a link between the actual stage of reform in the candidate countries and the acknowledgment that the Copenhagen political criteria had been met. ${ }^{2}$ It happened only after Croatia's accession that the European Commission suggested various adjustments to the negotiation procedure. ${ }^{3} \mathrm{How}^{-}$ ever, not only were the conditionality requirements not taken seriously, but their maintenance was also missing after accession. ${ }^{4}$ The only case where the EU expressed some doubts and extended the validity of pre-accession values-promotion in the form of a post-accession monitoring was the so-called Cooperation and Verification Mechanism applicable to Bulgaria and Romania, which remained in force even after they became full members..$^{5}$ (During the 2012 Romanian constitutional crisis, the Commission successfully used the circumstance that the mechanism had been expected to be discontinued as leverage. ${ }^{6}$ )

The weakness of the Copenhagen criteria and the lack of their application after accession caused a discrepancy between EU accession conditions and membership obligations, which might be one of the reasons for non-compliance after accession in some of the new Member States. The other reason is certainly the authoritarian past of the new democracies. Even though the immediate cause

1 The Croatian enlargement was somewhat special, as it was part of the EU's Stabilization and Association Policy, and the conditionality too was different. Inter alia, it included the collaboration with the ICTY. I am grateful to Elizabeth van Rijckevorsel for pointing this out.

2 D. Kochenov, 'Behind the Copenhagen façade. The Meaning and Structure of the Copenhagen Political Criterion of Democracy and the Rule of Law', European Integration Online Papers (EIoP), Vol. 8, No. 10, 2004, available at: http://eiop.or.at/eiop/pdf/2004-010.pdf (last accessed 28 April 2017).

3 See C. Hillion, 'Enlarging the European Union and Deepening Its Fundamental Rights Protection', European Policy Analysis, June Issue, 2013, p. 6.

4 About the so-called 'Copenhagen dilemma' see C. Closa, 'Reinforcing EU Monitoring of the Rule of Law', in C. Closa \& D. Kochenov (Eds.), Reinforcing Rule of Law Oversight in the European Union, Cambridge University Press, 2016, p. 15-35.

5 M. Vachudova \& A. Spendzharova, ‘The EU's Cooperation and Verification Mechanism: Fighting Corruption in Bulgaria and Romania after EU Accession', SIEPS European Policy Analysis, Vol. 1, 2012.

6 See Á. Bátori, 'Defying the Commission: Creative Compliance and Respect for the Rule of Law in the EU’, Public Administration, Vol. 94, No. 3, 2016. 
might have been the Austrian 'Haider affair'7, as Wojciech Sadurski rightly argues, the history of the Central and Eastern European candidate countries was the main reason why Article 7 TEU was revised in the Treaty of Nice. This new provision made it possible not only to react to a Member State's serious and persistent breach of principles mentioned in then-Article 6(1) TEU, but also to intervene in case there is a 'clear risk' thereof. ${ }^{8}$

The weakening of liberal constitutional democracy in Hungary started after the landslide victory of the centre-right Fidesz party in the 2010 parliamentary elections. This article presents how this process evolved and how little EU law and EU institutions could do to obviate the dismantling of liberal constitutional democracy in a Member State.

\section{B The 'Constitutional Counter-Revolution' after 2010}

Hungary was one of the first and most thorough political transitions, which provided all the institutional elements of constitutionalism: checks and balances and guaranteed fundamental rights. Hungary also represents the first, and probably model, case of constitutional backsliding from a full-fledged liberal democratic system to an illiberal one with strong authoritarian elements.

The seriousness of the core values of the EU can be examined through Hungary's deliberate non-compliance with the principles of constitutional democracy, because it has not yet received significant external sanctions or substantial internal opposition. Therefore, the case has broader implications for Europe, and it even has resonance in some other, especially former communist, countries of the region.

The characteristic of system change that Hungary shared with other transitioning countries was that it had to establish an independent nation-state, a civil society, a market economy and a democratic structure all together. ${ }^{9}$ Plans for transforming the Stalin-inspired 1949 Rákosi Constitution into a 'rule of law' constitution were delineated in the National Roundtable Talks of 1989 by partici-

7 In 2000, the far-right Freedom Party, headed by Jörg Haider, became the coalition partner of the centre-right government, which led to unilateral measures by the Member States against Austria. But this action has left the Member States and the Union institutions extremely reluctant to use similar mechanisms. As the 'report of the three wise men' mentions, the measures taken were perceived by the Austrian public as politically motivated sanctions by foreign governments against the Austrian population and therefore fostered nationalist sentiments. For a detailed analysis of the genesis of Art. 7 see F. Hoffmeister, 'Enforcing the EU Charter of Fundamental Rights in Member States: How Far are Rome, Budapest and Bucharest from Brussels?', in A. von Bogdandy \& P. Sonnevend, Constitutional Crisis in the European Constitutional Area. Theory, Law and Politics in Hungary and Romania, London, Hart Publishing, 2015, p. 202-205.

8 W. Sadurski, 'Adding a Bite to the Bark? A Story of Article 7, EU Enlargement, and Jörg Haider', Columbia Journal of European Law, Vol. 16, 2010, p. 394.

9 The terms 'single' and 'dual' transitions are used in A. Przeworski, Democracy and the Market: Political and Economic Reforms in Eastern Europe and Latin America, 1991. Later, Claus Offe broadened the scope of this debate by arguing that post-communist societies actually faced a triple transition, since many post-communist states were new or renewed nation-states. See C. Offe, Varieties of Transition: The East European and East German Experience, New York, MIT Press, 1997. 
pants in the Opposition Roundtable and representatives of the state party. Later, the illegitimate Parliament only rubber-stamped the comprehensive amendment to the Constitution, which came into effect on 23 October 1990, the anniversary of the 1956 revolution. This was the basic document of the 'constitutional revolution' until 1 January 2012.

Before the 2010 elections, most voters had grown dissatisfied not only with the government, but also with the transition itself, more than in any other East Central European country. ${ }^{10}$ Fidesz fed these sentiments by claiming that there had been no real transitions in 1989-1990, and that the previous 'nomenklatura' had merely converted its lost political power into economic influence, pointing to the previous two prime ministers of the Socialist Party, both of whom became rich after the transition owing to privatization. The populism of the Fidesz party was directed against all elites, including the elites who designed the 1989 constitutional system (in which Fidesz had also participated), claiming that it was time for a new revolution. That is why Viktor Orbán, the head of Fidesz, characterized the results of the 2010 elections as a "revolution of the ballot boxes". His intention with this revolution was to eliminate all kinds of checks and balances and even the parliamentary rotation of governing parties. In September 2009 Orbán made a speech in which he predicted that there was "a real chance that politics in Hungary will no longer be defined by a dualist power space. Instead, a large governing party will emerge in the centre of the political stage [that] will be able to formulate national policy, not through constant debates, but through a natural representation of interests". Orbán's vision for a new constitutional order - one in which his political party occupies the centre stage of Hungarian political life and puts an end to debates over values - has now been entrenched in a new constitution, which entered into force in April 2011. ${ }^{11}$

In its opinion, approved at its plenary session of 17-18 June 2011, the Council of Europe's Venice Commission expressed its concerns about the document,

10 In 2009, 51\% of Hungarians disagreed with the statement that they are better off since the transition, and only $30 \%$ claimed improvements. (In Poland $14 \%$ and $23 \%$ in the Czech Republic reported worsening conditions, and $70 \%$ and $75 \%$, respectively, perceived improvement.) Eurobarometer, 2009.

11 In an interview on Hungarian public radio on 5 July 2013, elected Prime Minister Orbán responded to European Parliament critics regarding the new constitutional order by admitting that his party did not aim to produce a liberal Constitution. He said: "In Europe the trend is for every constitution to be liberal, this is not one. Liberal constitutions are based on the freedom of the individual and subdue welfare and the interest of the community to this goal. When we created the constitution, we posed questions to the people. The first question was the following: what would you like; should the constitution regulate the rights of the individual and create other rules in accordance with this principle, or should it create a balance between the rights and duties of the individual? According to my recollection, more than $80 \%$ of the people responded by saying that they wanted to live in a world where freedom existed but where welfare and the interest of the community could not be neglected and that these need to be balanced in the constitution. I received an order and mandate for this. For this reason, the Hungarian constitution is a constitution of balance, and not a side-leaning constitution, which is the fashion in Europe, as there are plenty of problems there." See A. Tavares jelentés egy baloldali akció (The Tavares report is a leftist action), Interview with PM Viktor Orbán, 5 July 2013. Kossuth Rádió. 
which was drawn up in a process that excluded the political opposition and professional and other civic organizations. ${ }^{12}$

Before 1 January 2012, when the new Constitution came into effect, the Hungarian Parliament had been preparing a blizzard of so-called cardinal - or super-majority - laws, changing the shape of virtually every political institution in Hungary and making the guarantee of constitutional rights less secure. These legal regulations affect the rights on freedom of information, prosecutions, nationalities, family protections, the independence of the judiciary, the status of churches, functioning of the Constitutional Court and elections to the Parliament. In the last days of 2011, the Parliament also enacted the so-called Transitory Provision to the Fundamental Law, which claimed constitutional status and partly supplemented the new Constitution even before it came into effect. These new regulations had detrimental effects on the political independence of state institutions, for the transparency of lawmaking and the future of human rights in Hungary.

On 11 March 2013, the Hungarian Parliament added the Fourth Amendment to the country's 2011 Constitution, re-enacting a number of controversial provisions that had been annulled by the Constitutional Court. Requests were rebuffed by the European Union (EU), the Council of Europe and the US government urging the government to seek the opinion of the Venice Commission before bringing the amendment into force. The most alarming change concerning the Constitutional Court was that the amendment annulled the precedential value of all court decisions prior to the Fundamental Law's entry into force. On the one hand, this makes sense: old constitution = old decisions; new constitution = new decisions. But the Constitutional Court had already worked out a sensible new rule for the constitutional transition by deciding that in those cases where the terminology of the old and new constitutions were substantially the same, prior decisions would still be valid and could still be used as precedents. In cases where the new Constitution substantially diverged from the old one, earlier decisions would no longer be used. Constitutional rights are key provisions that are the same in the old and new constitutions - accordingly, as a matter of practice, the Fourth Amendment annuls primarily the decisions that defined and protected constitutional rights and harmonized domestic rights protection with European human rights law. With the removal of these fundamental Constitutional Court decisions, the government undermined legal security with respect to the protection of constitutional rights in Hungary. These moves renewed serious doubts about the state of liberal constitutionalism in Hungary and Hungary's compliance with its international commitments under the Treaties of the European Union and the European Convention on Human Rights.

In April 2014, Fidesz, with $44.5 \%$ of the party-list votes, won the elections again, and owing to 'undue advantages' for the governing party provided by the

12 Seewww.venice.coe.int/webforms/documents/CDL-AD(2011)016-E.aspx (last accessed 28 April 2017). Fidesz's counterargument was that the other parliamentary parties excluded themselves from the decision-making process with their boycott, except Jobbik, which voted against the document. 
amendment to the electoral system, ${ }^{13}$ it acquired a two-thirds majority in the Parliament. In early 2015, Fidesz lost its two-thirds majority as a consequence of mid-term elections in two constituencies. However, the far-right Jobbik received $20.5 \%$ of the party-list votes, so opponents of liberal democratic values still enjoy the support of the overwhelming majority of voters, who are not concerned about the backsliding of constitutionalism.

\section{The EU's Failed Efforts to Protect European Values}

Despite the fact that the EU has direct legal authority to protect the values of constitutionalism in the Member States, it preferred to use indirect means of pressure, largely dependent on EU economic competences. ${ }^{14}$ Until 2013, when the Fourth Amendment to the Fundamental Law was enacted, the EU did not use any of its capacities. In March 2013, after the Fourth Amendment was introduced to the Hungarian Parliament, the Danish, Finnish, Dutch and German Ministers of Foreign Affairs issued a Joint Letter, which called for a new mechanism to safeguard the fundamental values of the EU, secure compliance, and for the Commission to take an increased role in it. Later, the European Parliament's Committee on Civil Liberties, Justice and Home Affairs (LIBE) prepared a report on the Hungarian constitutional situation, including the impact of the Fourth Amendment to the Fundamental Law of Hungary. ${ }^{15}$ The report is named after Rui Tavares, a Portuguese Member of the European Parliament (MEP) at that time, who was the rapporteur of this detailed study of Hungarian constitutional developments since 2010. On 3 July 2013, the report passed with a surprisingly lopsided vote: 370 in favour, 248 against and 82 abstentions. In a Parliament with a slight majority of the right, this tally gave the lie to the Hungarian government's claim that the report was merely a conspiracy of the left.

With its acceptance of the Tavares Report, the European Parliament has created a new framework for enforcing the principles of Article 2 TEU. The report called on the European Commission to institutionalize a new system of monitoring and assessment.

The first reaction of the Hungarian government was not a sign of willingness to comply with the recommendations of the report but rather an outright rejection. Two days after the European Parliament adopted the report at its plenary session, the Hungarian Parliament adopted Resolution 69/2013 on 'the equal

13 "A number of amendments negatively affected the election process, including important checks and balances...The absence of political advertisements on nationwide commercial television, and a significant amount of government advertisements, undermined the unimpeded and equal access of contestants to the media" - international election monitors of the Organization for Security and Cooperation in Europe (OSCE) said in its report. See Statement of Preliminary Findings and Conclusions, International Election Observation Mission, Hungary - Parliamentary Elections, 6 April 2014.

14 See M. Dawson \& E. Muir, 'Hungary and the Indirect Protection of EU Fundamental Rights and the Rule of Law', German Law Journal, Vol. 14. No. 10, 2013.

15 www.europarl.europa.eu/sides/getDoc.do?type=REPORT\&reference=A7-2013-0229\&language= EN (last accessed 28 April 2017). 
treatment due to Hungary'. The document is written in first person plural as an anti-European manifesto on behalf of all Hungarians: "We, Hungarians, do not want a Europe any longer where freedom is limited and not widened. We do not want a Europe any longer where the Greater abuses his power, where national sovereignty is violated and where the Smaller has to respect the Greater. We have had enough of dictatorship after 40 years behind the iron curtain." The resolution argues that the European Parliament exceeded its jurisdiction by passing the report and creating institutions that violate Hungary's sovereignty as guaranteed by TEU. The Hungarian text also points out that behind this abuse of power there are business interests, which were violated by the Hungarian government's reduction of the energy costs of families. This Hungarian policy could allegedly undermine the interests of numerous European companies, which have gained, for years, extra profits abusing their monopoly in Hungary. In its conclusion, the Hungarian Parliament calls on the Hungarian government "not to cede to the pressure of the EU, not to let the nation's rights guaranteed in the fundamental treaty be violated, and to continue the politics of improving life for Hungarian families" ${ }^{16}$ These words very much reflect the Orbán government's view on the liberty of the state (or the nation) to determine its own laws: "This is why we are writing our own constitution...And we don't want any unsolicited help from strangers who are keen to guide us...Hungary must turn on its own axis."17

Encouraged by the Tavares report, Commission President Barroso also proposed a robust European mechanism to be "activated as in situations where there is a serious, systemic risk to the Rule of Law" ${ }^{18}$ Commission Vice-President Reding, too, announced that the Commission would present a new policy communication. ${ }^{19}$

Owing to the pressure, the Hungarian government finally made some cosmetic changes to its Fundamental Law, doing little to address the concerns set out by the European Parliament. The changes left in place provisions that undermine the rule of law and weaken human rights protections. The Hungarian Parliament, with a majority of its members from the governing party, adopted the Fifth

16 On the very day that the resolution of the Hungarian Parliament was announced, Hannes Swoboda (Austria), the leader of the S\&D Group at the European Parliament, said in a press release that the resolution was an 'insult to the European Parliament' and demonstrated that Hungary's Prime Minister, Viktor Orbán, does not yet understand the values of the EU. See Hungarian Parliament rejects Tavares report. Brussels, 5 July 2013, Agence Europe.

17 For the original, Hungarian-language text of Orbán's speech, entitled Nem leszünk gyarmat! [We won't be a colony anymore!] The English-language translation of excerpts from Orbán's speech was made available by Hungarian officials, see, e.g., Financial Times: Brussels Blog, 16 March 2012, available at: http://blogs.ft.com/brusselsblog/2012/03/the-eu-soviet-barroso-takes-onhungarys-orban/?catid=147\&SID=google\#axzz1qDsigFtC (last accessed 28 April 2017).

18 J.M.D. Barroso, 'State of the Union address 2013', Plenary session of the European Parliament (Strasbourg: 1 September, 2013) SPEECH/13/684. http://europa.eu/rapid/press-releaseSPEECH -13-684en.htm.

19 V. Reding, 'The EU and the Rule of Law - What Next?', Centre for European Policy Studies (Brussels: 4 September, 2013) SPEECH/13/677. http://europa.eu/rapid/pressreleaseSPEECH-13-677 es.htm. Last visited on 28 April 2017. 
Amendment on 16 September 2013. ${ }^{20}$ The government's reasoning states that the amendment aims to "finish the constitutional debates at international forum" (meaning with the EU - G.H.). A statement from the Prime Minister's Office stated: "[t]he government wants to do away with those... problems which have served as an excuse for attacks on Hungary." But this minor political concession does not really mean that the Hungarian government ever respected at least the formal rule of law, as some commentators claim. ${ }^{21}$

As none of the suggested elements have worked in the case of Hungary, the European Commission proposed a new EU framework to the European Parliament and the Council to strengthen the rule of law in the Member States. ${ }^{22}$ This framework is complementary to Article 7 TEU and the formal infringement procedure under Article 258 TFEU, which the Commission can launch if a Member State fails to implement a solution to clarify and improve the suspected violation of EU law. As the Hungarian case has shown, infringement procedures are usually too narrow to address the structural problems entailed by persistently non-compliant Member States. This happened when Hungary suddenly lowered the retirement age of judges and dismissed the most senior 10 percent of the judiciary, including a lot of court presidents, and members of the Supreme Court. The European Commission brought an infringement action, claiming age discrimination. The Court of Justice of the European Union (CJEU) in Commission v. Hungary established the violation of EU law. ${ }^{23}$ However, unfortunately, the decision was not able to reinstate the dismissed judges in their original positions and to stop the Hungarian government from keeping on relentlessly undermining the independence of the judiciary and weakening other checks and balances with its constitutional reforms. Apparently, the CJEU wanted to stay away from Hungarian internal politics, merely enforcing the existing EU law rather than evaluating the constitutional framework of a Member State politically. ${ }^{24}$ This was the reason that Kim Lane Scheppele suggested reframing the ordinary infringement proce-

20 Both the foreign and the Hungarian Human Rights NGOs said that the "amendments show the government is not serious about fixing human rights and rule of law problems in the constitution". See the assessment of Human Rights Watch: www.hrw.org/news/2013/09/17/hungaryconstitutional-change-falls-short (last visited on 28 April, 2017) and the joint opinion of three Hungarian NGOs: http://helsinki.hu/otodik-alaptorveny-modositas-nem-akarasnak-nyoges-avege (last accessed 28 April 2017).

21 See A. von Bogdandy, 'How to Protect European Values in the Polish Constitutional Crisis', verfassungsblog.de, 31 March 2016.

22 Communication from the Commission to the European Parliament and the Council of 11 March 2014, A new EU Framework to strengthen the Rule of Law, Brussels, 19 March 2014 COM(2014) 158 final/2 http://ec.europa.eu/justice/effective-justice/files/com_2014_158_en.pdf (last accessed 28 April 2017).

23 ECJ, 6 November 2012, Case C-286/12.

24 For the detailed facts of the case and the assessment of the ECJ judgement, see G. Halmai, "The Case of the Retirement Age of Hungarian Judges', in F. Nicola \& B. Davies (Eds.), EU Law Stories, Cambridge, Cambridge University Press, 2016. 
dure to enforce the basic values of Article 2 through a systematic infringement action. $^{25}$

The new framework allows the Commission to enter into a dialogue with the Member State concerned to prevent fundamental threats to rule of law. This new framework can best be described as a 'pre-Article 7 procedure', since it establishes an early warning tool to tackle threats to rule of law and allows the Commission to enter into a dialogue with the Member State concerned, in order to find solutions before the existing legal mechanisms set out in Article 7 will be used. The framework process is designed as a three-step procedure. First, the Commission assesses the situation in the Member State, collecting information and evaluating whether there is a systemic threat to rule of law. Second, if a systemic threat is found to exist, the Commission makes recommendations about how to resolve the issue. Third, the Commission monitors the response and the follow-up of the Commission's recommendations.

In June 2015, the European Parliament passed a resolution condemning Viktor Orbán's statement on the reintroduction of the death penalty in Hungary and his anti-migration political campaign, and called on the Commission to launch the Rule of Law Framework procedure against Hungary. ${ }^{26}$ But the Commission ultimately refused to launch the procedure on the argument that though the situation in Hungary raised concerns, there was no systemic threat to the rule of law, democracy and human rights. ${ }^{27}$

In December 2015, after the Hungarian Parliament enacted a series of antiEuropean and anti-rule-of-law immigration laws ${ }^{28}$ as a reaction to the refugee crisis, the European Parliament, again, voted on a resolution calling on the European Commission to launch the Rule of Law Framework. The Commission continued to use the usual method of infringement actions, finding the Hungarian legislation in some instances to be incompatible with EU law, in particular, the recast Asylum Procedures Directive (Directive 2013/32/EU) and the Directive on the right to interpretation and translation in criminal proceedings (Directive cedures', in C. Closa \& D. Kochenov (Eds.), Reinforcing Rule of Law Oversight in the European Union, Cambridge University Press, 2016, p. 105-132.

26 www.europarl.europa.eu/news/en/news-room/20150605IPR63112/hungary-meps-condemn-orb \%C3\%A1n\%E2\%80\%99s-death-penalty-statements-and-migration-survey (last accessed 28 April 2017).

27 Hungary: no systemic threat to democracy, says Commission, but concerns remain, Press Release, 2 December 2015.

28 See G. Halmai, 'Hungary’s Anti-European Immigration Laws', Tr@nsit Online, 4 November, 2015, available at: www.iwm.at/read-listen-watch/transit-online/hungarys-anti-european-immigrationlaws (last accessed 28 April 2017). 
2010/64/EU). ${ }^{29}$ This was the first time that the Commission has alleged a violation of the Charter of Fundamental Rights in an infringement action. ${ }^{30}$

\section{The Hungarian Reaction: National Constitutional Identity}

After the aforementioned legislative measures, the Hungarian government started a campaign against the EU's migration policy. The first step was a referendum initiated by the government. On 2 October 2016, Hungarian voters went to the polls to answer a single referendum question: "Do you want to allow the EU to mandate the relocation of non-Hungarian citizens to Hungary without the approval of the National Assembly?" Though $92 \%$ of those who cast votes and 98 of all the valid votes agreed with the government, answering 'no' (6\% were spoiled bal-

29 Regarding the asylum procedures, the Commission was concerned that there was no possibility to refer to new facts and circumstances in the context of appeals and that Hungary was not automatically suspending decisions in case of appeals - effectively forcing applicants to leave the territory before the time limit for lodging an appeal expired or before an appeal has been heard. Regarding rights to translation and interpretation, the Commission was concerned that he Hungarian law fast-tracked criminal proceedings for irregular border crossings, which did not respect provisions of the Directive on the right to interpretation and translation in criminal proceedings, which ensures that every suspect or accused person who does not understand the language of the proceedings is provided with a written translation of all essential documents, including any judgments. Also, the Commission expressed its concerns about the fundamental right to an effective remedy and a fair trial under Art. 47 of the Charter of Fundamental Rights of the EU. There were concerns about the fact that under the new Hungarian law dealing with the judicial review of decisions, in the event that an asylum application is rejected, a personal hearing of the applicant is optional. The fact that judicial decisions are taken by court secretaries (a sub-judicial level) that lack judicial independence also seems to be in breach of the Asylum Procedures Directive and Art. 47 of the Charter. http://europa.eu/rapid/press-release_IP-15-6228_en.htm (last accessed 28 April 2017).

30 See this option as one of three scenarios using the Charter as a treaty obligation in Hoffmeister, 2015, p. 201. (According to Hoffmeister, in the first scenario, a Charter right is further specified by EU secondary law. For example, Art. 8 Charter on the protection of personal data lies at the heart of Directive 95/46/EC, which largely harmonizes the rules on data protection in Europe. In the second scenario, the Charter right is not underpinned by specific EU legislation. That is the case, for example, with Art. 10(1) of the Charter on the freedom of thought, conscience and religion.) According to Armin von Bogdandy and his colleagues, national courts could also bring grave violations of Charter rights, such as freedom of the media in Art. 11, to the attention of the CJEU by invoking a breach of the fundamental status of Union citizenship in conjunction with core human rights protected under Art. 2 TEU. The idea behind this proposal is that the EU and Member States can have an interest in protecting EU citizens within a given member state. See A. von Bogdandy, M. Kottmann, C. Antpöhler, J. Dickschen, S. Hentrei \& M. Smrkolj, 'Reverse Solange. Protecting European Media Freedom Against EU Member States', Common Market Law Review, Vol. 49, No. 2, 2012. The proposal was released for public debate by the German-English language public law portal verfassungsblog.de in February 2012 (see A. von Bogdandy, M. Kottmann, C. Antpöhler, J. Dickschen, S. Hentrei \& M. Smrkolj, 'A Rescue Package for EU Fundamental Rights - Illustrated with Reference to the Example of Media Freedom', Verfassungsblog, 15 February 2012, available at: http://verfassungsblog.de/ein-rettungsschirm-fr-europischegrundrechte/Last visited on 28 April, 2017. The debate initiated by the editors (http:// verfassungsblog.de/category/schwerpunkte/rescue-english (last accessed 28 April 2017) featured comments by M. Hailbronner, D. Halberstam, D. Kochenov, M. Kumm, P. Lindseth, A. Katharina Mangold, D. Thym, W. Sadurski, P. Sonnevend, R. Uitz \& A. Wiener. 
lots), as the turnout was only around $40 \%$, the referendum was invalid. This was an own goal made by the Orbán government, which - after successfully using a popular referendum to overthrow its predecessor - made it more difficult to initiate a valid referendum. While the previous law required only $25 \%$ of the voters to cast a vote, the new law requires at least $50 \%$, failing which the referendum is invalid. According to the old law, all but one of the six referendums held since 1989 have been valid.

The referendum was announced by Prime Minister Viktor Orbán at the end of February 2016 to ask Hungarian voters whether to accept the September 2015 decision of the Council of the European Union on the mandatory quotas for relocating a total of 160,000 migrants over 2 years, of which Hungary would be obliged to take 1,294 altogether. In his announcement, Orbán said, "It is no secret that the Hungarian government refuses migrant quotas" and will be campaigning for 'no' votes. Orbán argued the quota system would "redraw Hungary's and Europe's ethnic, cultural and religious identity, which no EU organ has the right to do". Hungary's Foreign Minister added: "[w]e are challenging the quota decision at the European Court of Justice and we firmly believe that that decision was made with a disregard to EU rules."

The referendum question was legally challenged before the National Election Committee, which was authorized to approve the question. The challenge was based on Article 8(2) of the Fundamental Law, which states that "[n]ational referendums may be held about any matter falling within the functions and powers of the National Assembly." The petitioners stressed that since the Parliament had no jurisdiction over the European Council's binding decision on quotas, the question also violated the requirement of certainty regarding a question to be answered by referendum; notably, neither the voters nor the legislation will be aware of the legal consequences of the referendum. However, the Election Committee, the majority of which consisted of government appointees, approved the question, and so did the Supreme Court (Kúria) following an appeal. The Parliament officially approved the referendum with votes of the governing party, and the extreme right-wing opposition Jobbik party, while the left-wing opposition boycotted the plenary session. The Constitutional Court rejected the appeals against plans to hold the referendum, and, finally, the President of Hungary, a former Fidesz party member, set 2 October 2016 as the date for the plebiscite.

During the campaign the government aggressively promoted the 'no' votes, spending 15 billion forints or $€ 48.6$ million on the campaign, 7.3 times more than the cost of the Brexit campaigns. In early September, the government spent 4.1 million Euros on full-colour, B4-sized booklets to Hungarians at home and abroad making the government's case for why Hungarians should vote 'no'. 'Let's send a message to Brussels so they can understand too! We must stop Brussels! We can send a clear and unequivocal message to Brussels with the referendum. We must achieve that it withdraws the dangerous proposal."

The government did not even shy away from violating laws. For instance, the Supreme Court, in a case overturning a decision of the National Election Committee related to Hungarians living abroad, ruled that "campaign letters sent on 
behalf of the government to ethnic Hungarians abroad violated the principles of equal opportunity and citizens' entitlement to exercise their rights in a bona fide way". Also, ministry officials were making phone calls on behalf of Fidesz during working hours to voters in rural districts, encouraging them to vote 'no'. Prime Minister Orbán, in a speech at the plenary session of the Parliament, hinted that the globalist opposition planned to strike a deal with Brussels and resettle thousands of migrants in municipalities controlled by the fake left-wing parties. Hence, opposition-headed municipalities would have to take responsibility for not producing enough 'no' votes in the form of having to take in more refugees than other municipalities in the country. The chief of the Prime Minister's Office confirmed that the compulsory distribution of migrants to Hungary would result in cuts in social benefits - the recipients of which are, in many cases, Roma. This has been interpreted as a thinly veiled message to increase voter turnout among the Roma electorate. But the highlight of the hate-filled campaign was the announcement by the deputy chair of the parliamentary commission for national security that it would pursue a national security screening of 22 non-governmental organizations (NGOs) that were protesting against the inhumane politics of the Hungarian government against refugees and calling for the public to invalidate the referendum.

Despite all the immoral and unlawful efforts of the government to influence the Hungarian voters, the majority of them did not cast votes, rendering the referendum invalid. Disregarding this result, on the night of the referendum, Prime Minister Orbán announced an amendment of the Constitution "in order to give a form to the will of the people" and tried to push Brussels by claiming that "in an EU Member State today $92 \%$ of the participants said that they do not agree with the EU proposal; can Brussels force the quotas on us after this?"

Despite the fact that at the time of the referendum the idea of a constitutional amendment was not on the table, arguing with the 3.3 million Hungarians who voted in favour of the anti-EU referendum, Prime Minister Orbán introduced the Seventh Amendment to defend Hungarian constitutional identity to get an exemption from EU law in this area. The draft amendment touched upon the National Avowal, the Europe clause in the Foundation part, and two provisions in the part on Freedoms and Responsibilities.

Following the sentence "[w]e honour the achievements of our historical constitution and we honour the Holy Crown, which embodies the constitutional continuity of Hungary's statehood and the unity of the nation," the following sentence was to be inserted into the National Avowal: "[w]e hold that the defence of our constitutional self-identity, which is rooted in our historical constitution, is the fundamental responsibility of the state."

Paragraph 2 of the Europe clause (Article E) of the Fundamental Law was planned to be amended to read:

Hungary, as a Member State of the European Union and in accordance with the international treaty, will act sufficiently in accordance with the rights and responsibilities granted by the founding treaty, in conjunction with powers granted to it under the Fundamental Law together with other Member States 
and European Union institutions. The powers referred to in this paragraph must be in harmony with the fundamental rights and freedoms established in the Fundamental Law and must not place restrictions on the Hungarian territory, its population, or the state and its alienable rights.

The following new paragraph 4 would have been added to Article R: "(4) It is the responsibility of every state institution to defend Hungary's constitutional identity."

Paragraphs 1-4 of Article XIV were planned to be replaced with the following text.

1 No foreign population can be settled into Hungary. Foreign citizens, not including the citizens of countries in the European Economic Area, in accordance with the procedures established by the National Assembly for Hungarian territory, may have their documentation individually evaluated by Hungarian authorities.

2 Hungarian citizens on Hungarian territory cannot be deported from Hungarian territory, and those outside the country may return whenever they so choose. Foreigners residing on Hungarian territory may only be deported by means of legal proclamation. It is forbidden to perform mass deportations.

3 No person can be deported to a state, nor can any person be extradited to any state, where they are in danger, discriminated against, subject to persecution, or where they are at risk of any other form of inhumane treatment or penalty.

4 Hungary will provide asylum to non-Hungarian citizens if the person's country of origin or other countries do not provide protection, and also for those who, in their homeland or place of residence, are persecuted for their race, ethnicity, social standing, religion, or political convictions, or if their fear of persecution is well-founded.

All 131 National Assembly representatives from the Fidesz-KDNP governing coalition voted in favour of the proposed amendment, while all 69 opposition representatives either did not vote (66 representatives) or voted against the amendment ( 3 representatives). The proposed amendment thus fell two votes short of the two-thirds majority required to approve amendments to the Fundamental Law. Although Jobbik, in principle, supported the proposed Seventh Amendment, the party's MPs did not participate in the vote because the government had failed to satisfy Jobbik's demand that the Hungarian Investment Immigration Program, which grants permanent residency in Hungary to citizens of foreign countries who invest 300,000 Euros in government 'residency bonds', be abolished. ${ }^{31}$

After the failed constitutional amendment, the Constitutional Court appears to have come to rescue Orbán's constitutional identity defence of its policies, in particular as to migration. The Court carved out an abandoned petition of the Commissioner for Fundamental Rights, filed a year earlier, before the referendum

31 During the vote on the amendment, Jobbik MPs displayed a sign referring to the programme reading "He [or she] Is a Traitor Who Lets Terrorists in for Money!" 
was initiated. In his motion the ombudsman asked the Court to deliver an abstract constitutional interpretation of certain provisions of the Fundamental Law in connection with European Council decision 2015/1601 of 22 September 2015. He submitted the following four questions:

1 Whether the prohibition of expulsion from Hungary in Article XIV(1) of the Fundamental Law forbids only this kind of action by the Hungarian authorities, or if it also covers actions by Hungarian authorities which they use to promote the prohibited expulsion implemented by other states.

2 Whether under Article E(2), state bodies, agencies and institutions are entitled or obliged to implement EU legal acts that conflict with fundamental rights stipulated by the Fundamental Law. If they are not, which state organ can establish that fact?

3 Whether under Article E(2) the exercise of powers bound to the extent necessary may restrict the implementation of the ultra vires act. If state bodies, agencies and institutions are not entitled or obliged to implement ultra vires EU legislation, which state organ can establish that fact?

4 Whether Article XIV(1) and Article E can be interpreted in a way that authorizes or restricts Hungarian state bodies, agencies and institutions, within the legal framework of the EU, to facilitate the relocation of a large group of foreigners legally staying in one of the Members States without their expressed or implied consent and without personalized and objective criteria applied during their selection.

The Court in its decision 22/2016 (XII. 5.) $\mathrm{AB}^{32}$ rendered the petition admissible and decided to answer the first question related to the interpretation of Article $\mathrm{XIV}$ of the Fundamental Law in a separate judgment. Answering questions 2-4, the Court, relying on the German Federal Constitutional Court's methods of constitutional review of EU law, developed a fundamental rights review and an ultra vires review, the latter composed of a sovereignty review and an identity review. ${ }^{33}$

The fundamental rights review is based on Articles E(2) and I(1) of the Fundamental Law. The latter provision declares that " $\mathrm{t}]$ he inviolable and inalienable fundamental rights of MAN shall be respected. It shall be the primary obligation of the State to protect these rights." Having these rules in mind, and after referring to the Solange decisions of the German Federal Constitutional Court, and explicitly to Solange III of 15 December 2015 (2 BvR 2735/14), and the need for cooperation in the EU and the primacy of EU law, the Court stated that it cannot

32 The English language translation of the decision is available at the home page of the Hungarian Constitutional Court, available at: http://hunconcourt.hu/letoltesek/en_22_2016.pdf (last accessed 28 April 2017).

33 The German Federal Constitutional Court frequently referred to constitutional identity, but the ECJ has never acknowledged constitutional pluralism. Most recently, in the so-called OMT decision (Case C-62/14, Gauweiler and Others v. Deutscher Bundestag), the Luxembourg Court stridently defended the supremacy of EU law over national law. In those very rare cases when the ECJ acknowledges a Member State's constitutional identity, it is out of respect for a national legal institution, which was established at the moment of the state's foundation. (This happened in the Fürstin von Sayn-Wittgenstein judgment. Case C-208/09, Sayn-Wittgenstein v. Landeshauptmann von Wien [2011] E.T.M.R.12.) 
renounce the ultima ratio defence of human dignity and other fundamental rights. It further held that as the state is bound by fundamental rights, this binding force of the rights is also applicable to cases where public power, under Article E, is exercised together with EU institutions or other Member States.

Regarding the ultra vires review, the Court held that, under Article E(2), there are two main limits on conferred or jointly exercised competences: it can infringe neither the sovereignty of Hungary (sovereignty review) nor its constitutional identity (identity review). The constitutional foundation of the sovereignty review is Article $\mathrm{B}(1)$ of the Fundamental Law, which states that "Hungary shall be an independent, democratic rule-of-law State." Paragraphs (3) and (4) contain the standard sovereignty principle: "[t]he source of public power shall be the people," "[t]he power shall be exercised by the people through elected representatives or, in exceptional cases, directly." The Court warned that "Article E(2) should not empty Art B", and it reserved the "presumption of maintained sovereignty" 34 in relation to judging the common exercise of other competences that have already been conferred on the EU.

The identity test, the Court argued, was based on Article 4(2) TEU and on continuous cooperation, mutual respect and equality. Even if it sounds tautological, the Constitutional Court of Hungary interprets the concept of constitutional identity as Hungary's "self-identity." 35 Its content is to be determined by the Constitutional Court on a case-by-case basis based on an interpretation of the Fundamental Law as a whole and its provision in accordance with Article R(3), which states that "the provisions of the Fundamental Law shall be interpreted in accordance with their purposes, the National Avowal contained therein and the achievements of our historical constitution."

The Court held that

the constitutional self-identity of Hungary is not a list of static and closed values, but many of its important components - identical with the constitutional values generally accepted today - can be highlighted as examples: freedoms, the division of powers, republic as the form of government, respect of autonomies under public law, the freedom of religion, exercising lawful authority, parliamentarism, the equality of rights, acknowledging judicial power, the protection of the nationalities living with us. These are, among others, the achievements of our historical 17 constitution, the Fundamental Law and thus the whole Hungarian legal system are based upon. ${ }^{36}$

The Constitutional Court further established that

the constitutional self-identity of Hungary is a fundamental value not created by the Fundamental Law - it is merely acknowledged by the Fundamental Law. Consequently, constitutional identity cannot be waived by way of an 
international treaty - Hungary can only be deprived of its constitutional identity through the final termination of its sovereignty, its independent statehood. Therefore the protection of constitutional identity shall remain the duty of the Constitutional Court as long as Hungary is a sovereign State. Accordingly, sovereignty and constitutional identity have several common points, thus their control should be performed with due regard to each other in specific cases. ${ }^{37}$

Based on the foregoing, the Hungarian justices ruled that the Court itself can examine whether the EU's exercise of power violates first, human dignity or any other fundamental right, second, Hungary's sovereignty or, third, Hungary's constitutional identity rooted in its historical Constitution, and based on this examination, it has the power to override EU law in the name of constitutional identity.

Viktor Orbán's first jubilant reaction shows how enthusiastic he was that the Court has helped the government's ideals to come true by making up for the failed referendum and the Seventh Amendment: "I threw my hat in the air when the Constitutional Court ruled that the government has the right and obligation to stand up for Hungary's constitutional identity. This means that the cabinet cannot support a decision made in Brussels that violates Hungary's sovereignty", adding that the Court's decision is good news for "all those who do not want to see the country occupied." In the same interview, given to the Hungarian Public Radio, Orbán pointed out the next subject of national constitutional identity, referring to the latest EU plan to terminate Hungarian state regulation of public utility prices. He said that the European Commission incorrectly argued that competition in the energy sector leads to lower prices. "Therefore Hungary insists on reducing utility rate cuts and we shall defend it in 2017. Although this will be a very tough battle, we have a chance of success." 38

The next sign of this battle regarding asylum seekers was another speech that Viktor Orbán delivered in February 2017, in which he stated: "I find the preservation of ethnic homogeneity very important." 39 On 5 March, the same year, a newspaper reported on Hungary's shameful treatment of asylum seekers, including severe beatings with batons and the use of attack dogs. ${ }^{40}$ Two days after the report was published, on March 7, the Hungarian Parliament passed an amendment to the Asylum Act that forces all asylum seekers into guarded detention camps. ${ }^{41}$ While their cases are being decided, asylum seekers, including women

38 http://hvg.hu/itthon/20161202_Orban_beszed_pentek_reggel (last accessed 28 April 2017).

39 Speech delivered on 28 February 2017 at the annual gathering of the Hungarian Chamber of Commerce. See É.S. Balogh, 'Viktor Orbán's 'ethnically homogenious Hungary', The Hungarian Spectrum, 3 March 2017, available at: http://hungarianspectrum.org/2017/03/01/viktor-orbansethnically-homogeneous-hungary/.

40 The report from Belgrade was published in the Swedish newspaper Aftonblader, available at: www.aftonbladet.se/nyheter/a/noLbn/flyktingarna-den-ungerska-polisen-misshandlar-ochtorterar-oss.

41 www.upi.com/Top_News/World-News/2017/03/07/UN-Hungary-plan-for-refugee-camps-illegalharmful-to-children/4631488910166. 
and children over the age of 14 , will be herded into shipping containers surrounded by a high razor-fence on the Hungarian side of the border. ${ }^{42}$

\section{E The Latest European Responses}

On 14 March 2017, the European Court of Human Rights (ECtHR) found that the detention of two Bangladeshi asylum seekers for more than three weeks in a guarded compound without any formal, reasoned decision and without appropriate judicial review had amounted to a de facto deprivation of their liberty (Art. 5 of the Convention) and right to effective remedy (Art. 13). The Court also found a violation of Article 3 on account of the applicants' expulsion to Serbia insofar as they had not had the benefit of effective guarantees to protect them from exposure to a real risk of being subjected to inhuman and degrading treatment. ${ }^{43}$ It should be taken into account that this unlawful detention of the applicants in the transit zone was based on the less restrictive rules enacted in 2015.

On 26 April 2017, the European Parliament held a debate on Hungary. In his opening remarks First Vice-President Frans Timmermans said that the Commission shares the worries and concerns of many people within and outside the EU regarding recent developments in Hungary and about the compatibility of certain actions of Hungarian authorities with EU law and with the shared European values. This was the reason, Timmermans explained, that the College discussed the overall situation in Hungary first in its 12 April meeting, ${ }^{44}$ and again a couple of hours before the parliamentary debate. At this latter meeting, the College decided to start an Article 258 infringement action on the recent amendment to the Hungarian Higher Education Law, which aims at closing down the Central European University in Budapest. According to the Commission's statement, ${ }^{45}$ the law is not compatible with the fundamental freedoms of the internal market, notably the freedom to provide services and the freedom of establishment. However, the Commission also invoked the right of academic freedom, the right to education and the freedom to conduct a business as provided by the Charter of Fundamental Rights of the European Union, as well as the Union's legal obligations under international trade law. The Commission sent a Letter of Formal Notice to the Hungarian Government on this issue giving one month to respond to these legal concerns. As Timmermans reported, the draft legislation on the governmental

On the very same day that the Parliament voted for the bill, Viktor Orbán delivered a speech at the swearing-in-ceremony of 462 new 'border hunters'. In the speech Orbán described "migration as a Trojan horse of terrorism", and he also dismissed criticism of the new law as "charming human rights nonsense”. See É.S. Balogh, 'The Hungarian Government's Shameful Treatment of Asylum Seekers', The Hungarian Spectrum, 10 March 2017, available at: http:// hungarianspectrum.org/2017/03/09/the-hungarian-governments-shameful-treatment-of-asylum -seekers.

43 Judgment of 14 March 2017 in the case of Ilias and Ahmed v. Hungary (Application no. 47287/15).

44 http://europa.eu/rapid/press-release_SPEECH-17966_en.htm?utm_source=dlvr.it\&utm_ medium=twitter.

45 http://europa.eu/rapid/press-release_MEX-17-1116_en.htm. 
oversight of the so-called 'foreign' non-governmental organizations, a law that bears very close resemblance to President Putin's 'foreign agents' act, is also on the Commission's radar screen together with the new asylum law adopted at the end of March.

Apparently, the Commission did not want to impose an infringement action regarding the asylum regulation, because there was already a pending procedure on Hungarian asylum law. (In December 2015, after - as a reaction to the refugee crisis - the Hungarian Parliament enacted a series of anti-European and anti-ruleof law immigration laws in July and September, ${ }^{46}$ the European Parliament adopted a resolution calling on the European Commission to launch the Rule of Law Framework introduced in 2014. The Commission continued to use the usual method of infringement actions, finding the Hungarian legislation in some instances to be incompatible with EU law, specifically, the recast Asylum Procedures Directive and the Directive on the right to interpretation and translation in criminal proceedings. This was the first time that the Commission has alleged a violation of the Charter of Fundamental Rights in an infringement action.) In the current debate the First Vice-President also promised that the Commission continues to be attentive to the situation of the Roma in Hungary, especially to the discrimination against Roma children in education, which has also been the subject of a pending infringement procedure since May 2016. In his speech Timmermans also announced the Commission's response to the Hungarian government's 'Stop Brussels' consultation, in order to correct false claims and allegations made in the consultation. ${ }^{47}$

Prime Minister Viktor Orbán in his speech, on the one hand, called the debate on the Central European University (CEU) 'absurd', and based on falsehoods, but, on the other hand, claimed that George Soros and 'his NGOs' are attacking Hungary and want to transport one million migrants to the EU per year. ${ }^{48}$ Many MEPs in the debate, including Manfred Weber, the president of the European People's Party (EPP), where the Hungarian governing party, Fidesz, belongs, harshly criticized the Lex CEU, Guy Verhofstadt, the chairperson of the ALDE-group even asking Orbán whether the next step will be burning books on the square in front of the Hungarian Parliament. ${ }^{49}$ Verhofstadt, together with Frank Engel, MEP of the EPP-group from Luxembourg, accused the Hungarian prime minister of wanting to continue taking the EU's money but not its values. ${ }^{50}$

Therefore, for many of Hungary's critics, the obvious solution of the problem would be either a voluntary exit of the non-complying Member State from the EU altogether or imposition of financial sanctions by the EU. Orbán made it clear in his speech that he does not want to leave, but rather to reform the EU according to his illiberal liking. Serious financial sanctions, like the substantial curtailment

46 See Halmai, 2015.

47 http://en.euractiv.eu/wp-content/uploads/sites/2/2017/04/Commission-answers-Stop-BrusselsConsultation_EN.pdf.

48 www.miniszterelnok.hu/prime-minister-viktor-orbans-speech-in-the-european-parliament.

49 www.europarl.europa.eu/sides/getDoc.do?pubRef=-//EP//TEXT+CRE+20170426+ITEM $-014+\mathrm{DOC}+\mathrm{XML}+\mathrm{V0} / / \mathrm{EN} \&$ language=en\&query=INTERV\&detail=1-041-000.

50 www.zeit.de/politik/2017-04/verfahren-ungarn-eu-frank-engel-interview. 
of the structural funds, are only possible as a consequence of an Article 7 procedure, which - in 2015 after Hungary's cruel treatment of the refugees - was tabled by the ALDE-group, but finally rejected mostly because of the EPP's rejection. This means that the key issue regarding any EU move in the case of Hungary is whether the EPP is still protecting its member party, Fidesz. The recent parliamentary debate has also shown that there is a growing uneasiness within the group towards Orbán. ${ }^{51}$

The EPP's statement also proves that the group is not ready to go for serious measures against the Hungarian government. But even in the event of a willingness to trigger Article 7, there is another obstacle, which became clear after the failed rule of law procedure against Poland. At that moment European Commission President Jean-Claude Juncker told Belgian newspaper Le Soir that the socalled Article 7 procedure would lead to nothing "because some [EU] member states are already saying they will refuse to invoke it... This a priori refusal de facto invalidates Article 7". ${ }^{2}$ Juncker was referring to Hungary's veto in the case of Poland, but the same can be expected vice versa. This was the reason for Kim Scheppele's suggestion to start a joint Article 7 procedure against Poland and Hungary. ${ }^{53}$ According to Scheppele, this would be the only chance to avoid the two illiberal Member States' veto regarding the sanction against the other, because in her view a Member State, which is also warned under Article 7(1), cannot possibly veto the decision in the case of its 'fellow-traveller'. The legal question of whether such an exclusion can be derived from Article 7 TEU or from Article 354 TFEU could only be answered if the political decision on starting an Article 7 procedure were made in the first place.

Before triggering the Article 7 procedure, the Commission could also have started a Rule of Law Framework procedure against Hungary. In June 2015, the European Parliament passed a resolution condemning Viktor Orbán's statement on the reintroduction of death penalty in Hungary and his anti-migration political campaign, and called on the Commission to launch the Rule of Law Framework procedure. ${ }^{54}$ However, the Commission ultimately refused to launch the procedure on the ground that though the situation in Hungary raised concerns, there was no systemic threat to the rule of law, democracy and human rights. ${ }^{55}$ Finally, the first step to use the Rule of Law Framework was taken by the European Commission against Poland in early January 2016. But the framework proved to be useless in the Polish case because the Polish government refused to comply with either of the two recommendations submitted by the Commission.

51 www.politico.eu/article/viktor-orban-europe-meps-increasingly-back-kicking-out-of-epp.

52 http://en.europeonline-magazine.eu/juncker-eu-powerless-against-authoritarian-slide-in-polandhungary_493513.html.

53 See K.L. Scheppele, 'EU Can Still Block Hungary's Veto on Polish Sanctions', politico.eu, 11 January 2016.

54 www.europarl.europa.eu/news/en/news-room/content/20150605IPR63112/html/Hungary-MEPs -condemn-Orb\%C3\%A1n\%E2\%80\%99s-death-penalty-statements-and-migration-survey.

55 Hungary: no systemic threat to democracy, says Commission, but concerns remain, Press Release, 2 December 2015. 
Therefore, the pre-Article 7 procedure does not seem to be promising in the case of Hungary either.

With the infringement procedure regarding the CEU, the Commission chose the easier legal path, which is less promising to change the Hungarian government's authoritarian attitude not only because - as we saw in the asylum and the Roma segregation case - it may not even reach the CJEU, but also because - as another Hungarian case in 2012 has shown - infringement actions are usually too narrow to address the structural problem entailed by persistently non-compliant Member States. This happened in Commission v. Hungary, which was previously examined. ${ }^{56}$ The case was a source of inspiration for Kim Scheppele to suggest reframing the ordinary infringement procedure to enforce the basic values of Article 2 TFEU through a systemic infringement action. ${ }^{57}$

As the infringement action concerning the CEU mentions the violation of three different provisions of the Charter, the Commission could also have referred either to Article 2 TFEU or, for that matter, to the sincere cooperation requirement embedded in Article 4(3) TEU and test the CJEU's readiness to consider the systemic nature of the violations. But it is very unlikely that even a strong CJEU judgment could save the CEU and the Hungarian NGOs, because by the time any decision is made it will be too late for them. In other words, the legal solution will not ease the threat.

Nonetheless, 3 days after the debate, the possibility of a political solution arose, when the Hungarian prime minister was summoned to the Presidency of the EPP. According to the press release, "the EPP wants the CEU to remain open, deadlines suspended and dialogue with the US to begin." (Just a reminder: the Lex CEU requests a new international treaty with the 'American government', albeit that the federal government has no jurisdiction for such negotiations.) The EPP also stressed that "NGOs are an integral part of any healthy democracy, that they represent the civil society and that they must be respected." 58 Despite the Venice Commission's preliminary opinion regarding the Lex $\mathrm{NGO}^{59}$ on 13 June 2017 the Hungarian Parliament adopted the law with certain cosmetic amendments, therefore, the Venice Commission, in its final opinion, concluded that the law "will cause a disproportionate and unnecessary interference with the freedoms of association and expression, the right to privacy, and the prohibition of discrimination". 60

58 www.epp.eu/press-releases/prime-minister-orban-to-comply-with-eu-laws-and-epp-valuesfollowing-meeting-with-epp-presidency.

59 www.venice.coe.int/webforms/documents/?pdf=CDL-PI(2017)002-e.

60 Para 68. www.venice.coe.int/webforms/documents/default.aspx?pdffile=CDL-AD(2017)015-e. 


\section{F. Present and Future of Constitutionalism in Hungary}

The current Hungarian constitutional system constitutes a new, hybrid type of regime, between the ideal of a full-fledged democracy and a totalitarian regime. ${ }^{61}$ Even if there is a formal written constitution, an autocracy is not a constitutional system. ${ }^{62}$ Therefore, China, Vietnam, Cuba, Belorussia, the former Soviet Union and former communist countries cannot be considered constitutional systems, even though, as William J. Dobson argues, “today's dictators and authoritarians are far more sophisticated, savvy, and nimble than they once were." 63 What happened in Hungary is certainly less than a total breakdown of constitutional democracy but also more than just a transformation of the way the liberal constitutional system is functioning. Hungary became an illiberal and undemocratic system, ${ }^{64}$ which was the openly stated intention of Orbán. ${ }^{65}$ The Hungarian system represents an atypical form of hybrid regimes, because, as opposed to such approaches in Latin America, the former Soviet republics or Africa, where the basis is a presidential constitution, in Hungary the formal parliamentary system remained in place with the decisive role of the Prime Minister.

61 For the classic differentiation between totalitarian (dictatorial) and authoritarian systems, see J. Linz, Totalitarian and Authoritarian Regimes, 1975.

62 About totalitarian systems with written constitutions, see J. Balkin \& S. Levinson, 'Constitutional Dictatorship', Yale Law School, 2010.

63 W. Dobson, 'The Dictator's Learning Curve. Inside the Global Battle for Democracy', Doubleday, 2012, p. 4.

64 As Jan-Werner Müller rightly argues, it is not just liberalism that is under attack in these two countries but democracy itself. Hence, instead of calling them 'illiberal democracies' we should describe them as illiberal and 'undemocratic' regimes. See J.-W. Müller, 'The Problem with "Illiberal Democracy”', Project Syndicate, 21 January 2016.

65 In a speech delivered on 26 July 2014 before an ethnic Hungarian audience in neighbouring Romania, Orbán proclaimed his intention to turn Hungary into a state that "will undertake the odium of expressing that in character it is not of liberal nature." Citing as models he added: "We have abandon[ed] liberal methods and principles of organizing society, as well as the liberal way to look at the world... Today, the stars of international analyses are Singapore, China, India, Turkey, Russia. ... and if we think back on what we did in the last four years, and what we are going to do in the following four years, th[e]n it really can be interpreted from this angle. We are ... parting ways with Western European dogmas, making ourselves independent from them ...If we look at civil organizations in Hungary, ...we have to deal with paid political activists here...[T]hey would like to exercise influence ... on Hungarian public life. It is vital, therefore, that if we would like to reorganize our nation state instead of the liberal state, that we should make it clear, that these are not civilians...opposing us, but political activists attempting to promote foreign interests. ...This is about the ongoing reorganization of Hungarian state. Contrary to the liberal state organization logic of the past twenty years, this is a state organization originating in national interests." See the full text of Viktor Orbán's speech, available at: http://budapestbeacon.com/ public-policy/full-text-of-viktor-orbans-speech-at-baile-tusnad-tusnadfurdo-of-26-july-2014/ 10592 (last accessed 28 April 2017). 
The backsliding has happened through the use of 'abusive constitutional' tools: constitutional amendments and replacement. ${ }^{66}$ The case of Hungary has shown that both the internal and the external democratic defence mechanisms against this abusive use of constitutional tools have failed so far. The internal ones (constitutional courts, judiciary) failed because the new regimes managed to abolish all checks on their power, and the international ones, such as the EU toolkits, mostly owing to the lack of a joint political will to use them.

In this illiberal system the institutions of a constitutional state (Constitutional Court, ombudsman, judicial or media councils) still exist, but their powers are severely limited. Also, as in many illiberal regimes, fundamental rights are listed in the constitutions, but the institutional guarantees of these rights are endangered through the lack of an independent judiciary and Constitutional Court. To make it clear, competences of the constitutional courts, originally very strong at the beginning of the transition, can be weakened provided that they can still fulfil their function as checks and balances to the governmental power, or provided other control mechanisms exist.

As many scholars have noted, there is an incredible range of non-democratic, non-authoritarian regimes, and their relationship with each other and democracy is often imperfect and unclear. Countries in this 'grey zone' inspired a lot of concepts, which were created to capture the mixed nature of these regimes. Steven Levitsky and Lucas A. Way introduced the term 'competitive authoritarianism' for a distinctive type of 'hybrid' civilian regimes in which formal democratic institutions exist and are widely viewed as the primary means of gaining power, but in which incumbents' abuse of the state places them at a significant advantage vis-àvis their opponents. ${ }^{67}$

The hybridity of Hungarian constitutionalism differs from the authoritarian character of Putin's Russia, where on account of failing competing parties and candidates the results of parliamentary and presidential elections are uncertain. Therefore, the Russian regime can be considered authoritarian, while the Hungarian one is still democratic, even if illiberal.

66 The category of 'abusive constitutionalism' was introduced by David Landau using the cases of Colombia, Venezuela and Hungary. See D. Landau, 'Abusive Constitutionalism', UC Davis Law Review, Vol. 47, 2013, p. 189-260. Abusive constitutional tools are known from the very beginning of constitutionalism. The recent story of the Polish Constitutional Tribunal reminds one of the events in the years after the election of Jefferson as the first anti-federalist President of the United States. On 2 March 1801, the second last day of his presidency, President Adams appointed judges, most of whom were federalists. The federalist Senate confirmed them the next day. In response, Jefferson, after taking office, convinced the new anti-federalist Congress to abolish the terms of the Supreme Court that were to take place in June and December of that year, and Congress repealed the law passed by the previous Congress creating new federal judgeships. In addition, the anti-federalist Congress had begun impeachment proceedings against some federalist judges. About the election of 1800 and its aftermath see B. Ackerman, The Failure of the Founding Fathers. Jefferson, Marshall, and the Rise of Presidential Democracy, Cambridge, Harvard University Press, 2007.

67 See S. Levitsky \& L. Way, Competitive Authoritarianism. Hybrid Regimes After the Cold War, Cambridge, Cambridge University Press, 2010, p. 5. 
The case of Hungary proves that democracy and liberalism do not necessarily go hand in hand. Besides liberal democratic (or democratic and rule-of-law-oriented, 'rechsstaatlich') constitutions and political systems, there are non-liberal democratic ones (radical democracies without a bill of rights, such as most of the Commonwealth constitutions until very recently, or constitutions based on popular sovereignty giving little weight to the people's interest in the day-to-day politics, such as the constitutions of Latin American countries) and also liberal but non-democratic constitutions (such as the ones in France after 1815, or the constitutional system of the Austro-Hungarian Monarchy), and, finally, neither liberal nor democratic socialist constitutions (as the former and current communist countries). ${ }^{68}$

The problem with the Hungarian illiberal constitutional system is that the country is currently a member of the EU, which considers itself to be a union based on the principles of liberal democratic constitutionalism. Of course, the citizens of Hungary, as any other citizens of a democratic nation-state, have the right to oppose joint European measures, for instance on immigration and refugees, or even the development of a liberal political system altogether. However, this conclusion must be reached through a democratic process. There are still a significant number of people who either consider themselves supporters of liberal democracy or at least represent views that are in line with liberal democracy. If Hungarians ultimately opt for a non-liberal democracy, they must accept certain consequences, including parting from the EU and the wider community of liberal democracies.

\section{G Conclusion}

The described democratic backsliding in Hungary demonstrates that an institutional framework is a necessary but not sufficient element of a successful democratization. Behavioural elements, among them a political and constitutional culture, are as important as institutions. The other lesson of this case study is, on the one hand, that the very definition of democracy is changing, and it is not necessarily liberal. On the other hand, the borders between democratic, authoritarian or dictatorial regimes are blurred, and there are a lot of different hybrid systems,

Almost this same typology of constitutions and governance systems are used by the constitutional scholar Dieter Grimm, and the sociologists Iván Szelényi and Tamás Csillag. See D. Grimm, 'Types of Constitutions', in M. Rosenfeld \& A. Sajó (Eds.), The Oxford Handbook of Comparative Constitutional Law, Oxford University Press, 2012, p. 98-132; I. Szelényi \& T. Csillag, 'Drifting Liberal Democracy: Traditionalist/Neo-conservative Ideology of Managed Illiberal Democratic Capitalism in Post-communist Europe', Intersections, EEJSP, Vol. 1, No. 1, 2015, p. 18-48. Besides the four joint categories, Grimm adds a fifth type of constitution to his typology, namely the social or welfare state constitutions (such as the Indian, the Brazilian, the Japanese, the South Korean or the South African), which are not liberal regarding social and economic rights. 
such as the current Hungarian regime. ${ }^{69}$ Another important aspect of these developments is that emerging democracies, for instance the one in Tunisia, are not influenced exclusively by the liberal democratic West any more. ${ }^{70}$ Some economists claim that the real question is not why there are fewer and fewer liberal democracies, but why liberal democracies still exist. ${ }^{71}$ Others search for 'post-liberalism ${ }^{72}$ in the wake of the financial crisis and after Brexit. ${ }^{73}$

The behaviour of the Hungarian government, supported by the other three Visegrád countries, during the refugee crisis, has taught us that the strengthening of populist and extreme nationalist movements across Europe is incompatible with the values of the liberal democracy and that membership in the EU is not a guarantee for having liberal democratic regimes in all Member States. Unfortunately, an outsize fear of threats, lately (e.g. the refugee crisis and the Syrian conflict), strengthened illiberal systems, such as Turkey, and authoritarian regimes, such as Russia, all over Europe, and in the case of Hungary even inside the EU, ${ }^{74}$ not to mention Trump's presidency in the US. There is a growing gap between the old and the new Member States, and the support of populist parties has been strengthened even in the old Member States. ${ }^{75}$ EU institutions have so far proven incapable of enforcing compliance with core European values. After coming to the conclusion that the traditional mechanism of infringement procedures does not work, and in the fear from the unanimity requirement embedded in Article 7(2)

69 Asking the question whether liberal democracy is at risk, Ivan Krastev responds that the big difference compared to the 1930s is that even extremist parties do not contest the democratic aspect of the liberal democratic consensus. Instead, they have a problem with the liberal part of it. See I. Krastev, 'Europe in Crisis: Is Liberal Democracy at Risk?', in Democracy in Precipice, Council of Europe Democracy Debates 2011-2012. Council of Europe Publishing, 2012, p. 67-73.

70 See R. Youngs, 'Exploring “Non-Western” Democracy', Journal of Democracy, Vol. 26, No. 4, 2015.

71 S. Mukand \& D. Rodrik, 'The Political Economy of Liberal Democracy', Institute of Advance Study, Princeton, 2015. Joschka Fischer, former German foreign minister and vice-chancellor, gave an interesting explanation of what might have caused the decline of liberal democracy: "How did we get here? Looking back 26 years, we should admit that the disintegration of the Soviet Union - and with it, the end of the Cold War - was not the end of history, but rather the beginning of the Western liberal order's denouement. In losing its existential enemy, the West lost the foil against which it declared its own moral superiority." J. Fischer, 'Europe's Last Chance', Project Syndicate, 29 August 2016, available at: https://www.project-syndicate.org/ commentary/europe-needs-bold-leaders-by-joschka-fischer-2016-08 (last accessed 28 April 2017).

72 See J. Milbank \& A. Pabst, The Politics of Virtue, Post-Liberalism and the Human Future, Lanham, Rowman and Littlefield, 2016.

73 M. Kettle, 'Brexit Was a Revolt Against Liberalism, We Have Entered a New Political Era', The Guardian, 15 September, 2016.

74 At a conference in the Polish town Krynica, in mid-September 2016, Orbán and Kaczyński proclaimed a 'cultural counter-revolution' aimed at turning the EU into an illiberal project. A week later, at the Bratislava EU summit, the prime ministers of the Visegrád 4 countries demanded a structural change of the EU in favour of the nation states. Slawomir Sierakowski even speaks about an 'illiberal international'. S. Sierakowski, 'The Illiberal International', Social Europe, 13 September 2016.

75 Regarding the constitutional crisis of the EU, Michael Wilkinson draws attention to the dangers of 'authoritarian liberalism'. See M. Wilkinson, 'The Specter of Authoritarian Liberalism: Reflections on the Constitutional Crisis of the European Union', German Law Review, Vol. 14, 2013, p. 527. 
for sanctioning, the Commission duplicated the preventive mechanism of Article 7(1) by introducing the rule of law mechanism. Owing to political considerations, it was not used against Hungary at all, and in the case of Poland, despite the very strongly worded Commission recommendations and their disregard by the Polish government, nothing really happened. This considerably undermined not only the legitimacy of the Commission, but also that of the entire rule of oversight. The fear from Hungary's veto concerning Poland indicates that the desired oversight for the effective use of Article 7 TEU would require a treaty amendment. Unfortunately, the scenarios set out in the European Commission's White Paper on the Future of Europe ${ }^{76}$ published on 1 March 2017 does not advocate treaty changes and does not seem to provide institutional guarantees against populism and illiberal states within the EU. As we could see in the last two years, Poland led by Jaroslaw Kaczynski's PiS party, has been following the illiberal course of Viktor Orbán's Fidesz party. One may only hope that the EU will be able to protect the joint European constitutional values in all of its Member States. 